\title{
The Role of Lactate Dehydrogenase (LDH) Compared to Arterial Blood Gases (ABG) in Diagnosing Pneumocystis Carinii Pneumonia (PCP) in HIV/AIDS Patients on Routine Antiretroviral Therapy
}

\author{
Aulia Rahman', Tambar Kembaren², Endang Sembiring ${ }^{2}$, Putri C Eyanoer ${ }^{3}$ \\ ${ }^{1}$ Department of Internal Medicine, Faculty of Medicine, Universitas Sumatera Indonesia, Medan, Indonesia \\ ${ }^{2}$ Division of Tropical Medicine, Faculty of Medicine, Universitas Sumatera Indonesia, Medan, Indonesia \\ ${ }^{3}$ Department of Community and Preventive Medicine, Faculty of Medicine, Universitas Sumatera Utara
}

Corresponding Author: Aulia Rahman

\section{ABSTRACT}

Background: The lungs are one of the primary target organs for HIV disease and a major source of morbidity and mortality, among others, caused by Pneumocystis carinii pneumonia (PCP) or recurrent bacterial pneumonia. In developing countries, the incidence of PCP infection has soared, with high mortality rates ranging from $20 \%$ to $80 \%$. The increase in serum LDH plays an important role in determining the severity of the disease. This study aims to determine the role of LDH examination as a diagnostic tool for PCP and Arterial Blood Gases (ABG) in HIV and AIDS patients.

Method: This research is an analytical study using an observational diagnostic test design, conducted from November 2020-January 2021 at the HIV Treatment Room at H. Adam Malik Hospital, Medan with 158 subjects. We calculate the value of sensitivity, specificity, positive predictive value, and negative predictive value.

Results: $75.3 \%$ of the total sample was male, with the highest age group being 30-39 years old (46.2\%) 126 samples (79.7\%) had CD4 levels 200 cells $/ \mathrm{mm} 3,98$ samples (62\%) had LDH levels > $500 \mathrm{U} / \mathrm{L}$. In this study, 113 samples $(71.5 \%)$ fell into the $\mathrm{ABG}$ criteria [PaO2] $<70 \mathrm{mmHg}$ ). $\mathrm{LDH}$ has superior sensitivity and specificity value compared to $\mathrm{ABG}$ examination. In this case $\mathrm{PaO} 2$ or $\mathrm{A}-\mathrm{A}$ $\mathrm{DO} 2$ in diagnosing PCP in HIV-AIDS patients.
\end{abstract}

Conclusion: LDH examination combined with clinical and radiological examinations has good sensitivity and specificity in the diagnosis of PCP.

Keywords: HIV, AIDS, Lactate dehydrogenase, PCP

\section{INTRODUCTION}

The lungs are one of the primary target organs for HIV disease and a major source of morbidity and mortality, among others, caused by Pneumocystis carinii pneumonia (PCP) or recurrent bacterial pneumonia. ${ }^{[1]} \mathrm{PCP}$ infection was one of the first signs that the HIV/AIDS epidemic was starting in the United States. PCP soon became one of the leading AIDS-related diseases in the United States. In the late 1980s, about $30-40 \%$ of people with HIV/AIDS were diagnosed with PCP. ${ }^{[2]}$ In developing countries, the incidence of PCP infection has soared, with high mortality rates ranging from $20 \%$ to $80 \% .^{[3]}$ The incidence of $\mathrm{HIV}$-associated PCP is reported in varying amounts worldwide.

PCP is an important disease in HIV/AIDS patients in developing countries, with a high mortality rate. Before the widespread use of prophylactic antibiotics and antiretroviral therapy (ART), PCP 
occurred in $70 \%-80 \%$ of patients with AIDS; and in the disease's course, PCP was associated with a $20 \%-40 \%$ mortality rate in immunosuppressive individuals. Approximately $90 \%$ of PCP cases occur in patients with CD4 T-lymphocytes (CD4 cells) of $<200$ cells $/ \mathrm{mm} 3$. Other factors associated with a high risk of PCP include CD4+ cell percentage $<14 \%$, recurrent PCP, weight loss, and high plasma HIV RNA levels. ${ }^{[4]}$

LDH levels are often used as a marker of lung injury in PCP cases, and we associate their elevation with hypoxemia and have prognostic value. Serum lactate dehydrogenase (LDH) enzyme will be elevated in almost all cases of PCP over 250 IU/L. ${ }^{[5-7]}$ Elevated serum LDH levels in samples of PCP patients are due to the release of LDH from host cells in response to cytoplasmic membrane damage and damage, lungs because of pathogens. ${ }^{[8]}$ Elevated serum LDH is not specific enough to show lung parenchymal damage and in differentiating PCP from other types of pneumonia, but plays an important role in determining the severity of the disease. Decreased oxygen saturation as measured by pulse oximetry during exercise can diagnose PCP, especially in patients who have minimal symptoms, do not appear seriously ill, and have an atypical chest Xray. ${ }^{[9]}$

Although the gold standard for diagnosing PCP is PCR examination of airway specimens such as BAL fluid, many have obstacles in terms of the availability of examinations and these diagnostic measures cannot be carried out, especially with the COVID-19 pandemic (coronavirus disease 2019). ${ }^{[10]}$ However, early detection of PCP cases must still be done so that they can be treated immediately and prevent mortality. Therefore, researchers are interested in knowing the diagnostic accuracy of serum LDH compared to changes in Arterial Blood Gases (ABG) in diagnosing PCP in patients with HIV AIDS, especially at H. Adam Malik Hospital, Medan.

\section{MATERIALS AND METHODS}

This research is an analytic study using an observational diagnostic test design, carried out by collecting medical record data of HIV/AIDS patients diagnosed with and without PCP in the time interval of 2019. We plan data collection for 3 months, starting from November 2020-January 2021. We conducted this study at the Department of Internal Medicine, Faculty of Medicine, Universitas Sumatera Utara/ RSUP H Adam Malik Medan after obtaining approval from the Research Ethics Commission of the Faculty of Medicine, Universitas Sumatera Utara. There were 560 HIV/AIDS patients treated at the Haji Adam Malik General Hospital in Medan for the 2019 period, of which 158 HIV/AIDS patients met the criteria.

Each patient with risk factors and clinical symptoms of HIV underwent a rapid test and ELISA 3 methods to confirm the diagnosis of HIV AIDS. We included patients with confirmed HIV AIDS as subjects in this study. Examination of clinical signs and symptoms of PCP infection both clinically and radiologically confirmed diagnostic by ABG examination. We performed arterial blood sampling on research subjects to determine ABG levels as a biomarker of PCP infection.

The research subjects were divided into 2 groups, namely the first group was HIV-AIDS patients who showed clinical signs and symptoms of PCP infection (change in $\mathrm{ABG}$ value, namely [PaO2] 70 $\mathrm{mmHg}$ or difference in [AA] DO2 s $35 \mathrm{mmHg}$ ) and the second group was HIVAIDS patients who showed signs and symptoms of PCP infection, but changes in ABG values, namely [PaO2] $<70 \mathrm{mmHg}$ or differences in [AA] $\mathrm{DO} 2>35 \mathrm{mmHg}$. All research subjects underwent serum $\mathrm{LDH}$ examination, namely by taking venous blood from research subjects to determine serum LDH levels as a biomarker of PCP infection.

\section{Statistical Methods}

Univariate and bivariate analyzes were performed. Univariate analysis was 
Aulia Rahman et.al. The role of lactate dehydrogenase ( $L D H)$ compared to arterial blood gases $(A G)$ in diagnosing pneumocystis carinii pneumonia $(P C P)$ in HIV/AIDS patients on routine antiretroviral therapy.

performed to get the distribution of sample characteristics. We then tabulated the data in a $2 \times 2$ table to find the value of sensitivity, specificity, positive predictive value, and negative predictive value. We analyzed data using the computer program SPSS version 23 (Statistical Product and Service Solution) and a $95 \%$ confidence interval.

\section{RESULTS}

A total of $158 \mathrm{HIV} / \mathrm{AIDS}$ patients met the criteria in this study, we presented the characteristics of the subjects in this study in Table 1 . The majority of the study subjects were male, 119 people $(75.3 \%)$ with a median age of 35 years. The largest percentage of research subjects were 73 people (46.2\%) aged 30-39 years, and the smallest was 2 people $(1.3 \%)$ aged $<20$ years. There were 106 HIV-AIDS patients diagnosed with PCP (67.1\%) and 52 people
(32.9\%). The median CD4 level of HIV patients in this study was 27 cells $/ \mathrm{mm}^{3}$.

Table 1. Characteristics of the research sample.

\begin{tabular}{|l|l|}
\hline Characteristics & n $(\%)$ \\
\hline Gender & $119(75,3)$ \\
\hline Male & $39(24,7)$ \\
\hline Female & \\
\hline Age & $2(1,3)$ \\
\hline $20-29$ year-old & $37(23,4)$ \\
\hline $30-39$ year-old & $73(46,2)$ \\
\hline $40-49$ year-old & $35(22,2)$ \\
\hline$\geq 50$ year-old & $11(7,0)$ \\
\hline Diagnosis & \\
\hline PCP & $106(67,1 \%)$ \\
\hline Non-PCP & $52(32,9 \%)$ \\
\hline CD 4 levels & \\
\hline CD $4 \leq 200$ cells $/ \mathrm{mm}^{3}$ & $126(79,7 \%)$ \\
\hline CD $4>200$ cells $/ \mathrm{mm}^{3}$ & $32(20,3 \%)$ \\
\hline Median CD 4 & 27 cells $/ \mathrm{mm}^{3}$ \\
\hline
\end{tabular}

Differences in LDH levels and ABG parameters between HIV patients with PCP and non-PCP are presented in Table 2 . The median LDH levels of HIV-AIDS patients with PCP were higher than those without PCP, which were 526 (94-1072) U/L and 250 (7-2173) U/L, respectively.

Table 2. Median Minimum and Maximum LDH levels and Arterial Blood Gases (ABG) in HIV patients with PCP and non-PCP

\begin{tabular}{|l|l|l|l|l|l|}
\hline \multirow{2}{*}{ Parameter } & \multirow{2}{*}{ Unit } & HIV patients & Total & \multirow{2}{*}{ p-value } \\
\cline { 3 - 4 } & & PCP & Non-PCP & & \\
\hline $\mathrm{LDH}$ & $\mathrm{U} / \mathrm{L}$ & $526(94-1072)$ & $250(7-2173)$ & $511(7-2173)$ & 0,0001 \\
\hline $\mathrm{pH}$ & - & $7,47(6,94-7,68)$ & $7,45(6,94-7,68)$ & $7,47(6,94-7,68)$ & 0,645 \\
\hline $\mathrm{PaCO} 2$ & $\mathrm{mmHg}$ & $24(12-40)$ & $25(12-40)$ & $24(12-40)$ & 0,078 \\
\hline $\mathrm{PaO} 2$ & $\mathrm{mmHg}$ & $174,5(81-211)$ & $178,5(81-222)$ & $175(81-222)$ & 0,459 \\
\hline $\mathrm{HCO} 3$ & $\mathrm{mEq} / \mathrm{L}$ & $17,4(3,2-36,1)$ & $19,3(3,2-197)$ & $18,4(3,2-197)$ & 0,007 \\
\hline $\mathrm{TCO} 2$ & $\mathrm{mmol} / \mathrm{L}$ & $18,15(3,7-28,7)$ & $19,9(2,05-28,7)$ & $19,1(2,05-28,7)$ & 0,108 \\
\hline $\mathrm{BE}$ & $\mathrm{mEg} / \mathrm{L}$ & $-3,65(-21,2-6)$ & $-2,5(-27-6)$ & $-3,4(-27-6)$ & 0,123 \\
\hline $\mathrm{SaO} 2$ & $\%$ & $100(93-100)$ & $100(97-100)$ & $100(93-100)$ & 0,923 \\
\hline
\end{tabular}

The median HCO3 levels of HIVAIDS patients with PCP were lower than those of HIV-AIDS patients without PCP, which were 17.4 and 19.3 , respectively. The median TCO2 levels of HIV-AIDS patients with PCP were lower than those of HIVAIDS patients without PCP, which were 18.15 and 19.9, respectively. The median BE (base excess) levels of HIV-AIDS patients with PCP were higher than those of HIV-AIDS patients without PCP, which were -3.65 and -2.5 , respectively. The median $\mathrm{SaO} 2$ levels of HIV-AIDS patients with PCP are the same as those of HIVAIDS patients without PCP, which are $100 \%$ respectively.

The value of sensitivity, specificity, positive predictive value, the negative predictive value of LDH as a modality of PCP diagnosis in HIV and AIDS patients at H Adam Malik Hospital Medan is presented in Table 3. LDH has a sensitivity of $83.0 \%$, specificity $80.7 \%$, positive predictive value (positive predictive value) $89.7 \%$, and negative predictive value (negative predictive value) $70.0 \%$.

Table 3. Sensitivity value, specificity, positive predictive value, the negative predictive value of LDH as a modality of PCP diagnosis in HIV AIDS patients at H Adam Malik Hospital Medan

\begin{tabular}{|c|c|c|c|c|}
\hline & \multicolumn{2}{|l|}{ Gold standard } & \multirow[t]{2}{*}{ Total } \\
\hline & & PCP (+) Clinically (+) and CD4 $<200$ cells $/ \mathrm{mm}^{3}$ & PCP (-) Clinically (-) and CD4 $<200$ cells $/ \mathrm{mm}^{3}$ & \\
\hline LDH & $>500 \mathrm{U} / \mathrm{L}$ & 88 & 10 & 98 \\
\hline LDH & $\leq 500 \mathrm{U} / \mathrm{L}$ & 18 & 42 & 60 \\
\hline & Total & 106 & 52 & 158 \\
\hline
\end{tabular}


The values of sensitivity, specificity, positive predictive value, the negative predictive value of $\mathrm{ABG}$ examination as a modality of PCP diagnosis in HIV and AIDS patients at $\mathrm{H}$ Adam Malik Hospital Medan are presented in Table 4. ABG examination has a sensitivity of $69.8 \%$, specificity $25.0 \%$, predictive value positive (positive predictive value) $65.4 \%$, and negative predictive value (negative predictive value) $28,8 \%$.

Table 4 The value of sensitivity, specificity, positive predictive value, the negative predictive value of ABG as a modality of PCP diagnosis in HIV AIDS patients at H Adam Malik Hospital Medan

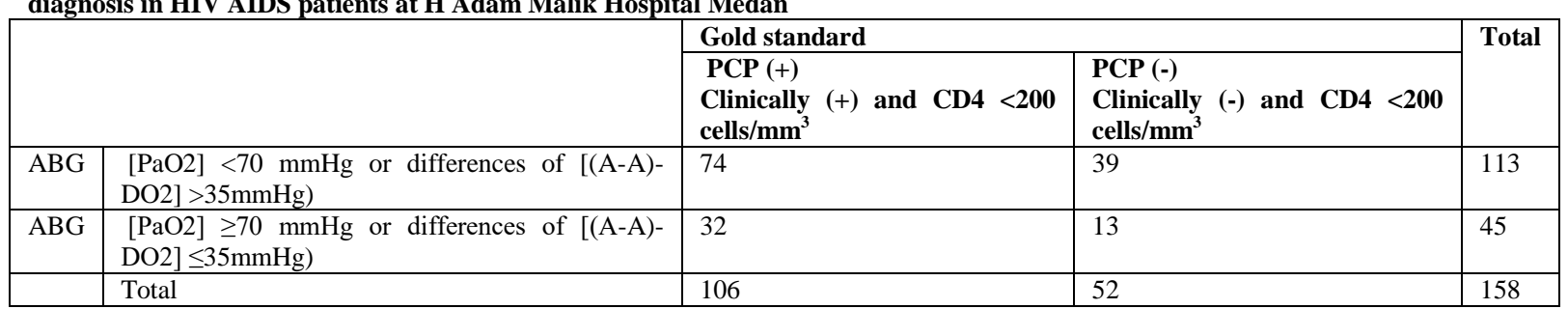

Based on the analysis of the diagnostic test above, we can conclude statistically that LDH levels have superior sensitivity and specificity compared to the
ABG examination as a diagnostic modality for PCP in HIV-AIDS patients at H Adam Malik General Hospital, Medan.

\begin{tabular}{|c|c|c|c|c|c|}
\hline & & $\begin{array}{l}\text { PCP (+) } \\
\text { Clinically (+) and CD4 }<200 \text { cells } / \mathrm{mm}^{3}\end{array}$ & $\begin{array}{l}\text { PCP (-) } \\
\text { Clinically (-) and CD4 }<200 \text { cells } / \mathrm{mm}^{3}\end{array}$ & & p-value \\
\hline $\mathrm{LDH}$ & $>500 \mathrm{U} / \mathrm{L}$ & 88 & 10 & $\begin{array}{l}98 \\
\end{array}$ & \multirow{3}{*}{0,0001} \\
\hline $\mathrm{LDH}$ & $\leq 500 \mathrm{U} / \mathrm{L}$ & 18 & 42 & 60 & \\
\hline & Total & 106 & 52 & 158 & \\
\hline
\end{tabular}

In the univariate analysis, the $\mathrm{p}$ value was 0.0001 . The confidence interval used is $95 \%$. Because the probability factor is less than $5 \%(\alpha=0.05)$, then this result is significant if the value of $\mathrm{p}<\alpha(\mathrm{p}=0.0001$.) so there is a relationship between LDH > $500 \mathrm{U} / \mathrm{L}$ and the incidence of PCP in HIV and AIDS patients at $\mathrm{H}$. Adam Malik Hospital Medan.

\section{DISCUSSION}

Based on this study, it is known that the incidence of HIV/AIDS patients diagnosed with Pneumocystis carinii pneumonia (PCP) infection at Haji Adam Malik General Hospital Medan is 106 (18.9\%) out of 560 HIV/AIDS patients treated at Haji Adam Malik General Hospital Medan in 2019. This study aims to determine the role of LDH examination as a diagnostic tool for Pneumocystis carinii pneumonia (PCP) and compare it with Arterial Blood Gases (ABG) in HIV/AIDS patients suspected of having PCP. In the study, most research subjects were male 119 people $(75.3 \%)$ with a median age of 35 years. Based on research data from patients who met the inclusion and exclusion criteria, 158 patients were studied and HIVAIDS patients diagnosed with PCP were $106(67.1 \%)$ and 52 people did not suffer from $\operatorname{PCP}(32,9 \%)$.

We consider this percentage quite high when compared to the patients studied, but this figure is still below the incidence of PCP related to HIV/AIDS worldwide, where the percentage of reported figures varies. In developing countries, the incidence of PCP infection has soared, with high mortality rates ranging from $20 \%$ to $80 \%$. $^{[3]}$ In Uganda, the frequency of PCP among HIVinfected patients with PCP ranges from 10 to $40 \% .^{[11]}$ Between 2000 and 2013, a European study reported an increase in the age and proportion of patients who had an episode of Pneumocystis jiroveci pneumonia (PJP) preceded by an HIV diagnosis (ages 34-44 years, and from $48 \%$ to $67 \%)^{[12]}$ PCP varies geographically, and some areas of the world have a low prevalence. ${ }^{[2]}$ 
Although PCP is rare in Africa and Asia, in India we found the number of PCP cases to vary from $6.1 \%$ to $60 \%$, while the prevalence of PCP cases in Thailand is between $7-25 \% .^{[13,14]}$ The prevalence of Pneumocystis jirovecii in 2017 in Indonesia was $14.5 \%$ among 55 AIDS patients with pneumonia (PCP). The prevalence data for the last 5 years based on sputum examination and bronchoalveolar lavage (BAL) is $28 \% .^{[15]}$ Recent data show the prevalence of PCP in 2018 was 20\%. ${ }^{[16]}$ The median CD4 levels of HIV patients in this study were 27 cells $/ \mathrm{mm}^{3}$ were $126(79.7 \%)$ HIV-AIDS patients with PCP in this study had CD4 levels of 200 cells $/ \mathrm{mm}^{3}$. Approximately $90 \%$ of PCP cases occur in patients with CD4 T-lymphocytes (CD4 cells) of $<200$ cells $/ \mathrm{mm}^{3}$. Other factors associated with a high risk of PCP include CD4+ cell percentage $<14 \%$, recurrent PCP, weight loss, and high plasma HIV RNA levels. $^{[4]} \mathrm{CD} 4+\mathrm{T}$ cells are also very important in infection, playing an important role in the function of memory cells to regulate the host inflammatory response by recruitment and activation of effector cells. ${ }^{[15]}$

Another study also by Stansel, et al, 1997 stated that low CD4+ levels had a strong correlation with the incidence of PCP ( $p<0.0001)$; were from these data, $79 \%$ of the 145 PCP cases had CD4 levels $<100$ cells/microliter and 95\% had CD4 levels < 200 cells/microliter. The univariate analysis also showed unexplained recurrent fever, night sweats, oropharyngeal thrush, and involuntary weight loss were strongly associated with the incidence of PCP in those with CD4 cell count $>200$. Even after multivariate analysis, CD4 cell count remained a powerful predictor of PCP incidence $(p<0.0001){ }^{[16]}$

Initially, the researchers planned to diagnose PCP based on the gold standard for PCR examination of respiratory tract specimens such as BAL fluid, but this examination was constrained to be carried out due to the COVID-19 pandemic so that it had obstacles in terms of operator availability and limited availability of examinations. $^{[17]}$ Therefore, in this study, the diagnosis of PCP is based on clinical, radiological, and supportive conditions in patients with HIV/AIDS who have symptoms of PCP, such as recurrent fever, shortness of breath, CD $4<200$ cells $/ \mathrm{mm}^{3}$, and radiologically supports a PCP manifestation.

In daily clinical practice, the diagnosis of PCP in HIV/AIDS patients is mostly based on clinical conditions. Nearly over 50 percent of cases have at least two of the following symptoms: the classic triad of clinical signs of unexplained fever $>37.7^{\circ} \mathrm{C}$ $\left(100^{\circ} \mathrm{F}\right)$ for over two weeks, dyspnea on exertion, and non-productive cough. ${ }^{[18]}$ In other studies, the gold standard used to compare the accuracy of the diagnosis of $\mathrm{LDH}$ and $\mathrm{ABG}$ can be as radiological and clinician examinations or compared with other causes of pneumonia such as CAP and pulmonary TB through methenamine silver stain from respiratory mucosal samples, then the viral load was calculated. ${ }^{[19,20]}$

Therefore, in this study, LDH levels can be a sensitive and specific diagnostic modality for diagnosing PCP in HIV patients apart from clinical manifestations that support a presumptive diagnosis and faster and more effective therapy. Where there are complaints of shortness of breath on activity or non-productive cough within 3 months of being sick, chest radiological features as bilateral diffuse interstitial infiltrates or bilateral diffuse pulmonary disease on gallium scans but there are normal radiological features in $10 \%$ of cases (the role of CT scans can be determined) shows a ground glass or cystic lesion, $\mathrm{PaO} 2$ $<70 \mathrm{mmHg}$ on examination Blood gas analysis, or low gas exchange capacity ( $<80 \%$ predictive value) or elevated $\mathrm{AaDO} 2$ and no evidence of bacterial pneumonia. ${ }^{[21]}$

\section{CONCLUSIONS}

We can use LDH examination as a diagnostic tool for Pneumocystis carinii pneumonia (PCP) in HIV AIDS patients because it has a sensitivity of $83.0 \%$, 
specificity of $80.7 \%$, the positive predictive value of $89.7 \%$, and negative predictive value of $70.0 \%$, where $\mathrm{LDH}$ has superior sensitivity and specificity value compared to $\mathrm{ABG}$ examination, in this case, $\mathrm{PaO} 2$ or $\mathrm{AA}$ DO2 in diagnosing PCP in HIV-AIDS patients.

\section{ACKNOWLEDGMENTS}

The Faculty of Medicine Universitas Sumatera Utara supported this research. The authors thank colleagues from the insert division here, Department of Internal Medicine for providing insight, help, and expertise that had helped authors throughout this research.

\section{Conflict of Interest: None}

\section{Source of Funding: None}

\section{Ethical Approval: Approved}

\section{REFERENCES}

1. Crothers, K., Morris, A., Huang, L. (2010). Pulmonary complications of human immunodeficiency viral infection $\left(5^{\text {th }}\right.$ ed) dalam Murray and Nadel's Textbook of Respiratory Medicine (hal.1925-1934). San Francisco, USA: Saunders

2. Center for Disease Control and Prevention (CDC). (2020). Pneumocystis pneumonia. Diakses tanggal 20 Oktober 2020. Available from:

https://www.cdc.gov/fungal/diseases/pneum ocystis-pneumonia/index.html

3. Linke, M. J., Rebholz, S., Collins, M., Tanaka, R., \& Cushion, M. T. (2003). Noninvasive method for monitoring Pneumocystis carinii pneumonia. Emerging infectious diseases, 9(12), 1613-1616. https://doi.org/10.3201/eid0912.030270

4. Kaplan, J.E., Hanson, D.L., Jones, J.L., Dworkin, M.S. (2001). Viral load as an independent risk factor for opportunistic infections in HIV-infected adults and adolescents. AIDS, 15(14), 1831-1836.

5. Vogel, M.N., Weissberger, P., Goeppert, B., et al. (2011) Accuracy of serum LDH elevation for the diagnosis of Pneumocystis jiroveci pneumonia. Swiss Med Wkly, 141: w13184.
6. Selwyn, P. A., Pumerantz, A. S., Durante, A., Alcabes, P. G., Gourevitch, M. N., Boiselle, P. M., \& Elmore, J. G. (1998). Clinical predictors of Pneumocystis carinii pneumonia, bacterial pneumonia, and tuberculosis in HIV-infected patients. AIDS (London, England), 12(8), 885-893. https://doi.org/10.1097/00002030199808000-00011

7. Truong J., Ashurst J.V. Pneumocystis Jiroveci Pneumonia. [Updated 2020 Aug 10]. In: StatPearls [Internet]. Treasure Island (FL): StatPearls Publishing; 2020 Jan-. Available from: https://www.ncbi.nlm.nih.gov/books/NBK4 82370/

8. Sokulska, M., Kicia, M., Wesolowska, M., Hendrich, A.B. (2015). Pneumocystis jiroveci- from a commensal to pathogen : clinical and diagnostic review. Parasitol Res, 114, 3577- 3585.

9. Leoung, G.S. (2006). Pneumocystosis and HIV. HIV InSite Knowledge Base Chapter. Available from: http://hivinsite.ucsf.edu/InSite?page=kb-0502-01

10. Agustina, D.R., Efiyanti, C., Yunihastuti, E., Ujainah, A., and Rozaliyani, A. (2017). Diagnosis dan Tata Laksana Pneumocystis Carinii Pneumonia (PCP)/Pneumocystis Jirovecii Pneumonia pada pasien HIV: Sebuah Laporan Kasus. Jurnal Penyakit Dalam Indonesia, 4(4), 209-213. http://dx.doi.org/10.7454/jpdi.v4i4.149

11. Huang, L., (2011). Clinical and translational research in pneumocystis and pneumocystis pneumonia. Parasite, 18(1), 3-11.

12. López-Sánchez, C., Falcó, V., Burgos J. (2015). Epidemiology and long-term survival in HIV-infected patients with Pneumocystis jirovecii pneumonia in the HAART era: experience in a university hospital and review of the literature. Medicine (Baltimore), 94(12), 681.

13. Ramakrishnan, K., Uma A, Senathipathy, R, Vijayaraj, Subramanian, P. T, Rathinasabapati, R, And Mondal, R. (2019). Pneumocystis Carinii Pneumonia in Hiv Infected Patients from South India. International Journal of Current Research, 11(06), 4525-4527. Doi: https://doi.org/10.24941/ijcr.35539.06.2019

14. Reynolds, S.J., Billioux, A.C., Quinn T.C.(2017). 99 - Hiv/Aids-Related Problems In Low- And Middle-Income Countries. 
Aulia Rahman et.al. The role of lactate dehydrogenase ( $L D H)$ compared to arterial blood gases $(A G)$ in diagnosing pneumocystis carinii pneumonia $(P C P)$ in HIVIAIDS patients on routine antiretroviral therapy.

Dalam Infectious Diseases (Fourth Edition), 2, 888-895.E1. https://doi.org/10.1016/b978-0-7020-62858.00099-X

15. Kelly, M.N., Shellito, J.E. (2010). Current understanding of pneumocystis immunology. Future Microbiol, 5(1), 43-65.

16. Stansell, J. D., Osmond, D. H., Charlebois, E., LaVange, L., Wallace, J. M., Alexander, B. V., Glassroth, J., Kvale, P. A., Rosen, M. J., Reichman, L. B., Turner, J. R., \& Hopewell, P. C. (1997). Predictors of Pneumocystis carinii pneumonia in HIVinfected persons. Pulmonary Complications of HIV Infection Study Group. American journal of respiratory and critical care medicine, 155(1), 60-66. https://doi.org/10.1164/ajrccm.155.1.90012 90

17. Wahyuningsih, R., Adawyah, R., Rozza, A., Denning, D.W., Prihartono, J., et al. (2017). Estimation of the serious mycoses burden in Indonesia, the congress of ESCMID, Vienna

18. Tjampakasari, C. (2018). Karakteristisasi Molekuler Gen Resistensi Dhps (Dihidropteroat Sintease) Dan Polimorfisme Gen Mtlsu (Mitochondrial Large Sub Unit) Pneumocystis Jirovecii Pada Odha Terduga
Pneumonia Di Jakarta. Disertasi Program Ilmu Biomedik, Jakarta: FKUI.

19. Sun, R., Lv, D., Xiao, M., et al. Diagnostic accuracy ofthe1,3-beta-d-glucan test and lactate dehydrogenase for pneumocystis pneumonia in non-HIV patients. Scientific Reports, $11, \quad 9226$. https://doi.org/10.1038/s41598-021-88729-z

20. Cilloniz, C., Torres, A., Polverione, E., Gabarrus, A., Amaro, R., Moreno, E., et al. (2014). Community-acquired lung respiratory infections in HIV-infected patients: microbial etiology and outcome. Eur Respir J, 43, 1698-1708. DOI: 10.1183/09031936.00155813

21. Yunihastuti E., Djauzi S., Djoerban Z. (2005). Infeksi Oportunistik pada HIV/AIDS, 39-43.

How to cite this article: Rahman A, Kembaren $\mathrm{T}$, Sembiring $\mathrm{E}$ et.al. The role of lactate dehydrogenase (LDH) compared to arterial blood gases $(\mathrm{AG})$ in diagnosing pneumocystis carinii pneumonia (PCP) in HIV/AIDS patients on routine antiretroviral therapy. International Journal of Research and Review. 2021; 8(10): 1-7. DOI: https://doi.org/10.52403/ijrr. 20211001 